\title{
TEMA PERCINTAAN DALAM TIGA CERITA PENDEK TERBITAN SURAT KABAR MANUNTUNG DI KALIMANTAN TIMUR (PERIODE 1988-1989)
}

\section{LOVE THEMES OF MANUNTUNG NEWSPAPERS' THREE SHORT STORIES IN EAST KALIMANTAN (PERIOD 1988-1989)}

\author{
Yudianti Herawati \\ Kantor Bahasa Provinsi Kalimantan Timur \\ Jalan Batu Cermin 25 Sempaja, Samarimda Utara \\ Posel: yudianti_bayu@yahoo.com
}

*) Naskah diterima: 10 September 2020; direvisi: 10 September 2020; disetujui: 6 Oktober 2020

\begin{abstract}
Abstrak
Tujuan penelitian ini untuk mendeskripsikan struktur cerita dalam tiga cerpenterbitan surat kabar harian Manuntung periode 1988-1989 yang difokuskan pada tema percintaan dan gejala sosial kultural. Masalah dalam penelitian ini meliputi (1) bagaimana bentuk struktur cerita dalam ketiga cerpen yang terbit di Manuntung, (2) bagaimanakah tema percintaan dalam ketiga cerpen yang terbit di Manuntung, dan (3) bagaimana pula gejala sosial kultural dalam ketiga cerpen yang terbit di Manuntung. Penelitian ini menggunakan metode deskriptif-kualitatif, sedangkan penerapan teori menggunakan struktural dengan menganalisis unsur intrinsik. Teknik analisis deskriptif digunakan untuk mendeskripsikan data-data cerpen yang diperoleh dari surat kabar Manuntung. Selain itu, teknik analitik juga digunakan untuk menentukan makna isi cerita dalam cerpen-cerpen tersebut sebagai objek penelitian. Hasil penelitian ini menunjukkan bahwa tema percintaan dalam ketiga cerpen tersebut menggambarkan kehidupan tokoh dengan berbagai pertikaian, peristiwa yang mengharukan, dan menyenangkan. Peristiwa-peristiwa itu mengandung kesan yang tidak mudah dilupakan oleh tokoh-tokoh dalam ketiga cerpen tersebut.
\end{abstract}

Kata kunci: struktur, intrinsik, percintaan, sosial, kultural

\begin{abstract}
The purpose of this study is to describe the structure of the story in three short stories of Manuntung daily newspapers in the period 1988-1989 which focuses on the theme of romance and sociocultural phenomena. It discusses about (1) the structure of the story, (2) the theme oflove, and (3) the sociocultural phenomena in Manuntung's three short stories. This study uses descriptive-qualitative methods and intrinsic structural theory. Descriptive analysis technique is used to describe the short story data. Analytical techniques are also used to determine the meaning of the story content in those short stories as the object of the research. The results of this study indicate that the theme of love portrays the characters' life of conflicts, touching moments, and happy times that are remembered by the them in those short stories.
\end{abstract}

Keywords: structure, intrinsic, romance, social, cultural 


\section{PENDAHULUAN}

Karya sastra dalam teori struktural merupakan sesuatu yang otonom. Teori ini menganggap bahwa di dalam karya sastra terdapat struktur yang dapat dipahami melalui unsur-unsur yang saling berkaitan untuk membentuk suatu kesatuan. Menurut Teeuw (2015:104), kritik sastra harus berpusat pada karya sastra itu sendiri, tanpa memperhatikan pengarang sebagai pencipta dan pembaca sebagai penikmat. Artinya, teori struktural mementingkan otonomi karya sastra, dengan mengaitkan usur-unsur di dalamnya untuk bisa mencari keutuhan makna dan menolak unsur-unsur yang di luar karya sastra itu sendiri. Dengan kata lain, otonomi karya sastra itu sebagai "dunia dalam kata" yang memiliki unsur intrinsik, yang dapat digali lebih detail lagi makna dari karya sastra itu sendiri (Teeuw, 2015: 105-106). Oleh karena itu, kajian struktural dipandang lebih objektif karena hanya berdasarkan sastra itu sendiri. Pada umumnya, penelitian yang dilakukan secara objektif tentu saja lebih menekankan aspek intrinsiknyadalam karya sastra (Endraswara, 2003:25).

Berdasarkan pendangan tersebut, keberadaan karya sastra Indonesia di Kalimantan Timur telah berlangsung sebelum Indonesia merdeka (1945). Ketika itu telah muncul puisi dan cerpen karya sastrawan Kalimantan Timur yang disebut sebagai pengarang Angkatan 45. Dalam perkembangannya, pengarang Angkatan 45 banyak menerbitkan karya-karyanya. Para sastrawan itu menerbitkan puisi melalui surat kabar atau harian pada tahun 1946, antara lain, dalam surat kabar Masyarakat Baru. Surat kabar harian Masyarakat Baru memiliki andil yang cukup penting dalam penerbitan sastra di Kalimantan Timur. Walaupun hanya terbit beberapa edisi dan dalam jumlah eksemplar yang terbatas, secara tidak langsung harian Masyarakat Baru telah mengilhami surat kabar yang muncul lebih belakangan dalam memasyarakatan karya sastra, seperti surat kabar Manuntung dan mingguan Sampe. Mingguan Sampe lahir dari keinginan kalangan sastrawan dalam memasyarakatkan dan memotivasi penciptaan karya sastra di Kalimantan Timur. Sebenarnya, harian Masyarakat Baru telah memiliki pembaca yang cukup luas. Surat kabar itu tidak hanya memuat karya sastra pengarang dari Samarinda,tetapi juga menerima puisi karya pengarang dari Tanjung Redeb, Tanah Grogot, bahkan dari Banjarmasih, Kalimantan Selatan (Herawati dkk., 2008:7-8).

Perkembangan cerita pendek di Kalimantan Timur lebih dulu muncul dibandingkan dengan kehadiran puisi. Hal itu juga dipengaruhi oleh peran media massa dalam memasyarakatkan karya cerpen. Penerbitan cerpen mulai menggeliat sejak terbitnya harian Manuntung dan media massa lainnya, seperti Meranti, Kaltim Post, Suara Kaltim, Samarinda Post, Membangun Bumi Etam, dan Tribun Kaltim. Akan tetapi, dalam perkembangan terakhir, pemuatan cerita pendek di surat kabar tidak konsisten. Bahkan, hadirnya rubrik sastra di surat kabar sangat tergantung dari perhatian dan kepedulian redaksi terhadap sastra. Dalam perkembangan selanjutnya, cerita pendek disosialisasikan dalam bentuk penerbitan antologi cerita pendek yang dilakukan oleh beberapa komunitas sastra di Kalimantan Timur.

Surat kabar harian Manuntung terbit di Kota Balikpapan dan Samarinda sejak 1988 dan 2003. Kemudian, pada tahun 1999 surat kabar Manuntung berubah nama menjadi Kaltim Post. Beberapa cerpen yang terbit di surat kabar harian Manuntung tahun 1988 1989 memuat tema realita sosial, polemik keluarga, dan kisah percintaan. Cerpen-cerpen tersebut antara lain, "Kemuning Senja" Karya Bening Budhilesmana (April 1988), "Hanya Sesaat" Karya Wie EkoS. (Mei 1988), 
"Antara Yogya-Balikpapan" Karya Irpus (Juni 1988), “Dermaga Biru” Karya Sukardhi Wahyudi (Juli 1988), "Penjual Koran” Karya Udi Banjar (Agustus 1988) "Di Atas Tempaan Lalah" Karya Iin E Birawono (Oktober 1988), "Dari Sebuah Kegagalan" Karya Ifta Larisya (November 1988), "Buntut" Karya Roedy Rachmaddi Masykoer Boenna (Desember 1998), "Pijar Sepasang Mata" Karya Herr Trunajaya (Januari 1989), "ParuParu" Karya Adam A. Chevny (Januari 1989), "Kisah Cinta yang Tertunda" Karya Tono Umpira (Februari 1989), “Ketika Mahakam Berhenti Mengalir" Karya Roedy R. Masykoer Boenna (Maret 1989), "Salah Langkah" Karya Jaka Pribadi (April 1989), “Tangis Duka Itu Tertunda" Karya Puri BK (April 1989), dan "Kidung Nostalgia Suatu Masa" Karya DP.Tono (Mei 1989).

Berdasarkan uraian tersebut, tujuan penelitian ini untuk mendeskripsikan struktur cerita dalam tiga cerpenterbitan surat kabar harian Manuntung periode 1988-1989 dengan tema percintaan dan gejala sosial kultural. Ketiga cerpen itu adalah (1) "Kemuning Senja" Karya Bening Budhilesmana (April 1988), (2) "Hanya Sesaat" Karya Wie Eko S. (Mei 1988), dan (3) "Antara Yogya-Balikpapan" Karya Irpus (Juni 1988). Selain itu, penelitian ini diharapkan dapat membangun sikap masyarakat agar dapat menghargai dan bangga terhadap cerpen-cerpen yang terbit pada media massa di Kalimantan Timur, baik masa angkatan'45, Orde Baru maupun reformasi.

Masalah dalam penelitian ini menitik beratkan analisis struktur cerita dalam tiga cerpen terbitan surat kabar harian Manuntung periode 1988-1989. Rumusan masalahnya meliputi (1) bagaimana bentuk struktur cerita dalam ketiga cerpen yang terbit di Manuntung, (2) bagaimanakah tema percintaan dalam ketiga cerpen yang terbit di Manuntung, dan (3) bagaimana pula gejala sosial kultural dalam ketiga cerpen yang terbit di Manuntung.

\section{LANDASAN TEORI}

Dalam sebuah cerita fiksi, lazimnya ada tokoh utama, konflik utama, dan tema utama. Ketiganya ini tidak dapat dipisahkan dan memiliki keterkaitan yang padu. Pelaku atau pemilik konflik utama pasti adalah tokoh utama, dan di situlah letak tema utama. Artinya dalam upaya menafsirkan tema sebuah novel harus mengaitkan ketiga unsur tersebut karena tema utama pasti ada dalam keterkaitan tiga unsur tersebut. (Nurgiyantoro, 2015:137). Sementara itu, analisis struktural difokuskan pada unsur-unsur intrinsik pembangunnya. Hal itu dapat dilakukan dengan mengidentifikasi, mengkaji, dan mendeskripsikan fungsi dan hubungan antarunsur intrinsik fiksi yang bersangkutan (Nurgiyantoro, 2013:60). Pendekatan struktural sebagai suatu kesatuan yang utuh, dapat membentuk suatu makna yang menyeluruh.

Selanjutnya, Wellek dan Werren (1990: 77-338) berpendapat bahwa karya sastra itu dapat didekati secara intrisik dan ekstrisik. Pendekatan intrisik terpusat pada struktur karya sastra, sedangkan pendekatan ekstrisik tertuju pada hal-hal di luar sastra. Artinya, dalam memahami karya sastra secara utuh, pendekatan ekstrisik dapat dilakukan dengan melihat unsur instrinsiknya karena pada umumnya karya sastra dibagun melalui analisis struktural. Pada dasarnya, teori struktural adalah suatu disiplin yang memandang karya sastra sebagai suatu struktur yang terdiri atas beberapa unsur yang saling berkaitan antara yang satu dengan yang lainnya (Sangidu, 2004:16).

Pendekatan struktural dapat dipandang sebagai pendekatan objektif. Struktur merupakan komponen paling utama, yang membentuk karya sastra. Kajian struktur 
dapat ditempuh dengan cara melakukan identifikasi, pengkajian, dan pendeskripsian fungsi dan unsur intrinsik yang membangun sebuah karya fiksi (Kasnadi dan Sutejo, 2010:4). Analisis struktural pada dasarnya bertujuan untuk memaparkan secermat mungkin fungsi dan keterkaitan antarunsur karya sastra yang secara bersama menghasilkan sebuah keseluruhan. Sementara itu, Stanton (dalam Sugihastuti 2012: 20-71), menyatakan bahwa struktur karya sastra meliputi fakta cerita, sarana sastra, dan tema. Fakta cerita meliputi karakter, alur, dan latar. Ketiga unsur tersebut sering disebut Stanton sebagai struktur faktual cerita karena peristiwa yang ada dapat dibayangkan oleh pembaca. Struktur Faktual akan membentuk pola sederhana untuk menyampaikan tema cerita. Selain fakta cerita, sarana sastra juga penting untuk dibahas karena sarana sastra tidak bisa dipisahkan dari struktur karya sastra. Sarana-sarana paling signifikan di antara berbagai sarana yaitu karakter utama, konflik utama, dan tema utama. Tiga sarana itu setiap bagiannya juga harus terhubung demikian erat (Stanton dalam Sugishatuti, 2012:51).

Berdasarkan beberapa pendapat tersebut, untuk memahami unsur instrinsik tema dalam cerpen terbitan surat kabar Manuntung, penelitian ini lebih mengarah pada pendapat Stanton. Menurutnya, tema merupakan aspek cerita yang sejajar dengan 'makna' dalam pengalaman manusia yang selalu diingat. Ada banyak cerita yang menggambarkan dan menelaah kejadian atau emosi yang dialami manusia seperti cinta, derita, rasa takut, kedewasaan, keyakinan, pengkhianatan manusia terhadap diri sendiri, disilusi, bahkan usia tua. Begitu pula dengan sarana-sarana sastra dapat diartikan sebagai metode (pengarang) memilih dan menyusun detail cerita agar ter- capai pola-pola yang bermakna (Robert Stanton, 2012:36-37).

\section{METODE PENELITIAN}

Kajian ini bersifat kualitatif, sedangkan metode pengumpulan data yang digunakan ialah metode diskriptif struktural, yaitu dengan cara menganalisis unsur intrinsik. Artinya, data yang digunakan merupakan deskripsi kata-kata atau ungkapan kualitatif. Penelitian ini menggunakan metode deskriptif analitik, sedangkan teori yang digunakan adalah pendekatan intrinsik. Teknik analisis deskriptif digunakan untuk mendeskripsikan data-data cerpen yang telah diperoleh di surat kabar Manuntung. Selain itu, teknik analitik juga digunakan untuk menentukan makna isi cerita dalam cerpen-cerpen tersebut sebagai objek penelitian.

Data-data tersebut dikumpulkan melalui metode pustaka. Secara pustaka, data penelitian diperoleh dari dokumen tertulis, misalnya hasil penelitian, artikel, surat kabar, dan sumber tertulis lainnya

\section{HASIL DAN PEMBAHASAN}

Karya sastra yang lahir dari seorang pengarang memiliki tema atau makna yang ingin disampaikan. Hal tersebut membuat tema sangat penting untuk dikaji karena tema merupakan gagasan utama sebuah cerita. Setiap cerita fiksi memiliki makna atau tema, tetapi tema yang terkandung dalam cerita fiksi bersifat implisit atau tidak disampaikan secara langsung. Untuk menentukan tema perlu adanya pemahaman dan penafsiran dari unsur-unsur yang berkaitan, yaitu fakta cerita dan sarana sastra. Selain itu, tema dapat juga dibagi menjadi dua bagian, yaitu tema bawahan atau tema minor dan tema sentral atau tema mayor. Tema minor adalah makna yang terdapat pada bagian-bagian tertentu cerita 
atau makna tambahan. Sementara itu, tema mayor menjadikan cerita berfokus dan saling memiliki keterkaitan antara satu unsur dengan unsur yang lain, untuk membentuk makna cerita yang utuh. Oleh karena itu, analisis tema percintaan dalam tiga cerpen terbitan surat kabar Manuntung di Kota Balikpapan pada periode 1988 1989 dapat dipahami secara detail dan jelas, baik melalui tema minor (bawahan) maupun tema mayor (sentral). Dengan kata lain, melalui analisis struktur tema pembaca dapat mengerti maksud dan makna yang terkandung di dalam ketiga cerpen tersebut.

\section{Cerpen "Kemuning Senja" Karya Bening Budhilesmana (April 1988)}

\subsection{Ringkasan Cerita}

Sore itu, Mira berada di suatu tempat yang sangat sepi. Letaknya di tengah hamparan persawahan yang cukup jauh dari rumah penduduk. Orang-orangmenyebut tempat itu dengan nama kemuning senja. Suasananya sepi dan angker.Senja pun mulai merambah di sekeliling pohon kemuning. Mira yang sudah dari tadi berada di tempat itu merasa gelisah karena menunggu seseorang yang tak kunjung datang. Mira ingin menepati janjinya kepada seseorang yang sudah enam bulan menjadi kekasihnya. Mira sangat mencintainya, meskipun keduanya berbeda suku dan agama. Pemuda itu benama Swi, keturunan Cina. Swi sosok pemuda yang tekun, rajin, dan ramah. Perbedaan suku dan agama tidak menjadikannya mider pada temanteman sebayanya. Rasa patriotisme yang dimiliki oleh Swi pada pemuda dan pemudi di Dusun Asambagus sangat disenangi oleh masyarakat setempat sehingga mereka mengangkat Swi sebagai ketua umum organisasi kepemudaan.

Dalam kesendiriannya menantikan Swi, Mira tampak gelisah. Ia semakin kesal dan dongkol. Senja pun perlahan mulai teng- gelam. Mira merasa ketakutan berada di tempat itu karena teringat sosok Umi, gadis kampung yang meninggal gantung diri di pohon mahoni dekat pohon kemuning. Rasa cemas, gelisah, dan ketakutan menghantui pikiran Mira. Kecemasan Mira berangsur pudar ketika Ia melihat bayangan yang sedang mendekatinya. Mira merasa lega dan beranggapan bahwa yang datang mendekatinya itu adalah Swi, kekasih yang sejak sore tadi ditunggunya. Dengan perasaan gembira, Mira kembali berdiri di bawah pohon kemuning. Ia tidak ketekutan lagi karena Swi akan mendekat dan memeluknya. Begitu banyang itu berada tepat di depannya, Mira terkejut, ternyata bukan sosok Swi melainkan Pomat, seorang pemuda yang kehilangan akal sehatnya karena ditinggal meninggal kekasihnya yang bernama Umi. Pomat mengira Mira adalah Umi, lalu Ia mengejar dan memenggil-manggil nama Umi. Mira pun kembali ketakutan dan bersembuyi dibalik pohon.

Sementara itu, Swi terus mengayuh sepadanya menelusuri jalan menuju pohon kemuning. Ia merasa bersalah karenaterlambat menemui Mira. Dengan kecapatan yang kencang, tiba-tiba sepada Swi menabrak tubuh seseorang, ternyata Mira. Keduanya terjatuh. Seketika Mira marah pada Swi karena ingkar janji. Swi berajak sambil membersihkan debu di baju Mira. Swi meminta maaf pada Mira karena terlambat datang dengan alasan membantu Ayahnya di kebun memetik sayur pesanan Ibu Hendra. Dengan perasaan kesal, takut, dan dihantui oleh bayang-bayang Umi di sekitar pohon mahoni, akhirnya sepasang kekasih itu saling memaafkan. Keduanya menaiki sepeda dan berboncengan. Swi terus mendayung sepedanya, butir-butir keringat mulai membasahi tubuhnya. Hati kedua remaja yang sedang menjalin cinta itu diliputi perasaan bahagia. 


\subsection{Tema Percintaan}

Cerpen "Kemuning Senja" mengangkat tema percintaan. Pembukaan cerita ditunjukkan melalui penantian seorang gadis bernama Mira yang sedang dirundung kegelisahan pada kekasihnya bernama Swi, pemuda keturunan Cina. Kisah percintaan Mira dan Swi terjalin selama enam bulan saat mereka sekolah bersama. Suatu hari Mira mengajak Swi bertemu di suatu tempat sepi bernama kemuning senja yang terletak di tengah hamparan sawah dan sangat jauh dari rumah penduduk. Mira sengaja memilih tempat itu pada waktu sore menjelang senja. Ketika Mira sudah berada di tempat itu, Swi belum menampakkan dirinya. Lalu Mira duduk sendiri di bawah pohon kemuning sambil mengawasi gerak burungburung bangau terbang rendah menuju sarangnya. Mira pun kembali teringat tentang kepribadian Swi dan Papanya, seorang petani sayur yang tinggal di Dusun Asambagus tidak jauh dari Kota Surabaya.

Walaupun Ia keturunan Cina, tapi sikap dan lakunya sudah seperti orang Indonesia asli. Bahkan di dusunnya, Swi terpilih sebagai ketua umum organisasi kepemudaan. Ternyata swi berhasil membangunkan rasa patriotism yang tinggi kepada muda-mudi dusun itu.

Papa Swi, bukan orang kaya.Tidak mempunyai toko serba ada, atau pun hotel yang berbintang, seperti lajimnya orang-orang Cina lainnya.Papa Swi Cuma seorang petani sayur di dusun Asambagus yang tidak jauh dari Kota Surabaya (Budhilesmana, 1988:V).

Dalam kutipan tersebut tokoh Mira sangat mengagumi dan membanggakan tokoh Swi, pemuda yang rendah hati dan berjiwa kesatria tidak membedakan suku, agama, dan golongan. Meskipun suatu saat Mira akan menghadapi hambatan dan rintangan oleh orang-orang di sekitarnya, karena perbedaansuku dan agama. Namun, ia akan terus mencintai dan menyayangi Swi. Kepribadian Swi yang suka membantu Papanya menjadi petani sayur, semakin menambah rasa cinta Mira pada Swi. Awalnya, alur dalam cerpen "Kemuning Senja" ini menggunakan alur flashback, yakni penceritaan kembali peristiwa-peristiwa yang terjadi pada masa lalu dalam lamunan tokoh utama (Mira). Kemudian, peristiwa selanjutnya menggunakan alur maju.

Mira mulai tidak betah. Ia merasa sangat takut! Setelah teringat Umi, yang tergantung di sebuah pohon mahoni yang tak jauh dari tempatnya. Dengan langkah-langkah kesal Mira mulai meninggalkan tempat itu. Tibatiba Ia terhenti, hatinya merasa lega ketika memandang sebuah bayangan yang menuju ke tempatnya. Dengan perasaan yang sangat gembira, Mira kembali ke bawah pohon kemuning.Ia sudah tidak takut lagi. Karena tidak lama lagi, Swi akan memeluknya (Budhilesmana, 1988:V).

Dalam kutipan tersebut, pengarang menggunakan alur maju yang ditandai dengan munculnya konflik di dalam cerita. Tokoh Mira mulai tampak kesal, dongkol, dan ketakutan berada di antara pepohonan yang rimbun. Harapan dan penantiannya bertemu Swi di bawah pohon kemuning menjadi sirna. Mira beranggapan bahwa Swi telah mengingkari janjinya. Dalam kecemasannya, muncul sebuah bayangan hitam mendekatinya. Mira mengira bayangan itu adalah Swi. Perasaan takut dan gelisah berangsur sirna, Mira berkhayal Swi akan mendekati dan memeluknya. Namun, harapan itu berubah menjadi ketakutan dan kecemasan. 
“Maaf Mir, karena Papa menyuruhku ke kebun memetik sawi yang di pesan Bu Hendra. " ucap Swi dengan nada lembut. "Kau sudah gila! Gara-gara janjimu aku menjadi kalang kabut." Suara Mira dengan nada marah

“Cepat! Jangan ribut. Kata Swi, yang mulai mendayung sepedanya. Swi terus mendayung sepedanya, butirbutir keringat mulai membasahi tubuhnya. Hati kedua remaja itu diliputi oleh perasaan bahagia (Budhilesmana, 1988:V).

Dalam kutipan tersebut, pengarang menyelesaikan bagian akhir cerita (resolusi) dengan cara pemecahan masalah. Permintaan maafSwi pada Mira awalnya tidak disambut baik oleh Mira. Kekecewaan Mira pada Swi membuat trauma mendalam sehingga perkataan kasar yang keluar dari mulut Mira tidak terkendalikan. Dengan rendah hati Swi membujuk Mira agar segera meninggalkan tempat itu karena situasinya sangat mencekam. Akhirnya, Mira bisa menerima permintaan maaf Swi. Mereka pulang berboncengan dengan sepeda yang dijalankan oleh Swi. Pertemuan kelabu di kemuning senja menyisakan cinta yang tidak terlupakan. Rajutan kebahagian sepajang jalan itu mampu menghapus ketakutan yang dialami Mira.

\subsection{Gejala Sosial Kultural}

Cerpen "Kemuning Senja" menceritakan gambaran kehidupan masyarakat pedesaan yang kental dengan kekerabatan, gotong royong, dan toleransi. Adapun gejala sosial kultural yang tercermin dalam cerpen ini adalah percintaan. Kisah percintaan sepasang remaja yang berbeda suku, golongan, dan keyakinan menjadi warna lokal dalam cerpen ini. Mira, gadis remaja yang polos dan bertubuh agak gemuk menjalin cinta dengan seorang pemuda keturunan Cina bernama Swi. Sementara itu, Swi yang memiliki kepribadian rendah hati dan penyayang sangat dikagumi oleh Mira. Gejala sosial kultural lainnya tergambar dalam kebiasaan Swi memiliki jiwa penolong dan bekerja keras membantu orang tua.

Sudah enam bulan Mira menjadi kekasih Swi. Walaupun mereka berlainan suku. Kelainan agama, rupanya tidak menjadikan problem dalam hubungannya

Swi tidak malu dengan pekerjaan Papanya. Sebelum berangkat ke sekolah, Swi selalu membantu Papanya untuk mengolah kebun sayur, yang sebagaian masih numpang dengan orang lain, dengan cara berbagi hasil panen.

Walaupun ia hanya keturunan Cina, ternyata Swi juga berhasil membangun rasa patriotisme yang tinggi kepada muda mudi dusun itu (Budhilesmana, 1988:V).

Kutipan tersebut menunjukkan kekuatan cinta Mira dan Swi yang tidak tergoyahkan, meskipun hambatan dan rintangan yang menghadang, mereka sanggup menghadapinya. Keduanya saling mengisi segala kekurangan dan kelebihan. Bahkan, Mira sangat mengagumi Swi yang memiliki keperibadian rendah hati, penolong, dan tidak malu membantu pekerjaan Papanya. Kondisiekonomi yang serba terbatas, dijadikannya sebagai cambuk untuk meraih kesuksesan di masa mendatang. Swi memang bukan orang pribumi, tetapi jiwa dan raganya sudah membumi di Indonesia, khususnya di Dusun Asambagus, Jawa Timur. Keterlibatannya dengan pemuda dan pemudi di dusun tersebut, menarik simpati warga untuk mengangkatnya menjadi ketua umum organisasi kepe- 
mudaan. Swijuga berhasil membangun rasa patriotisme yang tinggi pada remaja-remaja di dusun itu.

Entah, kenapa selama itu Swi belum juga muncul untuk menemui Mira yang sejak tadi menunggunya di bawah pohon kemuning itu. Kenapa ia sampai hati membiarkan Mira gelisah sendiri. "Sialan!" desahnya. Yang kemudian menyandarkan tubuhnya ke pohon kemuning, seakan Ia telah putus asa.Mira tampak seperti seekor singa yang kehilangan anaknya (Budhilesmana, 1988:V).

Kutipan tersebut memunculkan gejolak perasaan yang dialami Mira pada saat menanti kedatangan Swi. Kulit wajahnya yang kuning berubah kemerahan, pertanda kesabarannya telah sirna. Dalam kecemasan dan ketakutan itu, Mira merasa Swi telah mempermainkan perasaannya. Kemarahan yang diumpamakan seekor singa merupakan gejala sosial yang melanda batin tokoh.

Bayangan itu bukan Swi, melainkan tubuh yang kurus, kotor, serta berpakaian compang-camping. Tiba-tiba lelaki itu tertawa keras sambil menyebut nama umi. Mira sangat takut, tubuhnya gemetar.Wajahnya pucat, darahnya seakan terhenti. “Umi... kau masih hidup! Ayo Umi saying... jangan malu-malu. Hi....hi...hik. lucu... kenapa Kau sembunyi? Akukan pacarmu" (Budhilesmana, 1988: $\mathrm{V)}$.

Pada kutipan tersebut tokoh Mira memperlihatkan kelemahannya sebagai perempuan. Ia tidak mampu melawan rasa ketakutan yang mencekam batinnya. Pertemuan yang diharapkan berbuah kebahagiaan berubah menjadi malapetaka. Seorang lelaki yang kehilangan akal sehat- nya bernama Pomat telah behalusinasi membayangkan Mira adalah sosok Umi, kekasihnya yang meninggal dunia karena gantung diri di pohon mahoni. Ketakutan-ketakutan yang dialami Mira memunculkan konflik berkepanjangan dalam cerita ini sehingga si tokoh utama merasa kehilangan kepercaya diri untuk mengadapi permasalahan tersebut.

Swi, yang merasa ada janji dengan Mira terus mendayung sepedanya dengan sekuat tenaga. Ia takut akan kena omelan Mira. Putaran demi putaran sepeda itu meluncur laju. Tiba-tiba sepedanya menabrak tubuh Mira. Keduanya samajatuh. Swi segera memberi pertolongan."Kenapa kau lari-lari, Mira!" "Apa yang terjadi denganmu, Mir" tegas Swi yang merasa bersalah karena terlambat datang "untung orang itu tidak membunuh$\mathrm{ku}^{\prime \prime}$ Swi terkejut mendengar ucapan Mira itu. Ia tampak tegang (Budhilesmana, 1988:V).

Kutipan tersebut menunjukkan ketidakberdayaan Swi menepati janji dan melindungi kekasihnya, Mira. Swi tampak terpukul dan merasa bersalah telah membiarkan Mira menghadapi ketakutan dan cekaman seorang diri. Ia merasa egois dan kejadiannya akan serumit ini. Sementara itu, keputusasaan yang melanda batin Mira merupakan gejala sosial kultural yang dialami masyarakat pada umumnya. Kecemasan, ketakutan, dan ketidakberdayaan adalah potret kerapuhan seseorang yang bersifat manusiawi.

“Alasan! Jadi Kau lebih mementingkan Bu Hendra daripada Aku". Ucap Mira dengan kata ketus. "bukan begitu Mir, keduanya sangat penting bagiku."Ucap Swi. Keduanyadiam sejenak "Swi, Aku takut, ayo kita pergi 
dari tempat ini." Tegas Mira yang sejak tadi ketakutan.

Mira menutup matanya rapat-rapat, ketika melewati pohon mahoni yang tak begitu jauh dari pohon kemuning yang dipergunakan untuk menunggu Swi (Budhilesmana, 1988:V).

Kutipan tersebut menunjukkan kebimbangan tokoh Swi ketika menghadapi amarah yang di lontarkan Mira. Pada kenyataannya Swi memang salah telah mengingkari janjinya pada Mira. Namun, di sisi lain Swi harus membantu Papanya. Kecemburuan yang dirasakan Mira, sebagai pertanda bahwa Mira sangat mencintai Swi. Mira tidak merelakan jika Swi harus berbagi perhatian dengan orang lain (Bu Hendra). Namun, hal itu tidak mungkin dilakukan Swi. Menurut Swi, baik Mira maupun Papanya sangat penting dalam hidupnya. Sepasang kekasih itu hanya bisa berdiam sejenak. Suasana di sekitar pohon kemuning yang begitu mencekam meluluhlantakan hati Mira. Mira yang sedari tadi ketakutan tidak ingin lagi memasalahkan keterlambatan Swi. Ia ingin segera beranjak dari tempat itu. Bayangan wajah Umi menghantui pikirannya sehingga Ia tidak kuasa untuk membuka mata ketika melewati pohon mahoni yang digunakan Umi menggantung dirinya. Swi mulai memacu sepedanya sambil membonceng Mira. Sepanjang jalan hanya kenangan indah yang menggelayut di benak keduanya.

\section{Cerpen "Hanya Sesaat" Karya Wie Eko S. (Mei 1988)}

\subsection{Ringkasan Cerita}

Pertemuan Tika dengan Edward di halte, tempat pemberhentian kendaraan umum sangat tidak terduga. Edward, lelaki pertama yang pernah mengisi hatinya kini berubah dekil, kurus, dan hitam. Hampir tidak dapat dikenali oleh Tika. Seingat Tika, ketika masa SMA dahulu, Edward terkenal konyol dan badung. Nilai rapornya belum ada yang menandingi. Sekarang justru bertolak belakang. Keadaannya sungguh memprihatinkan. Pertemuan tidak terduga itu, mengingatkan kembali benih-benih cinta yang pernah mereka jalin. Tanpa disadari air mata Tika menetes membasahi pipinya. Edward pun segera beranjak dari duduknya lalu memanggil taksi. Kemudian Ia berlalu meninggalkan Tika sambil melambaikan tangan. Sempat terlontar perkataan dari bibir Edward akan ke rumah Tika nanti malam. Tika mengangguk sambil meneteskan air mata. Rasa rindu pada Edward tidak kuasa dibendungnya. Tanpa terasa senja mulai bergulir menandakan waktu berbuka puasa telah tiba.

Hari pun berganti malam. Tika tidak sabar menunggu kedatangan Edward, namun yang ditunggu tidak menepati janjinya. Hari pun terus berlalu, sudah empat malam Tika menunggu kedatangan Edward. Tika mulai gelisah. Kenapa Edward tidak menepati janjinya? Padahal sewaktu sekolah dulu, Edward tidak suka ingkar janji. Berbagai praduga menghantui pikiran Tika. Lamunan Tika kembali pada masa SMA, teringat akan kenekatan Edward memutuskan berhenti sekolah karena tidak sanggup menepati janjinya melunasi SPP dan uang gedung. Edward pun pergi ke Kalimantan seorang diri tanpa ada yang tahu, termasuk Tika.

Tika menarik napas sambil memandang ke arah jalan dan beraharap Edward menampakkan tubuhnya. Namun, hanya kesiasiaan saja. Kemudian Tika mengambil sebuah koran terbitan Manuntung Balikpapan, yang terletak di atas meja. Lembar per lembar dibuka Tika.Pada halaman kedua, mata Tika melotot. Ia membaca sebuah berita yang mengejutkan dan menyesakkan dadanya. Berita seorang lelaki muda berusia dua puluh tahun meninggal dunia karena 
ditabrak taksi penunpang di Jalan Mayjend Soetoyo. Saat diidentifikasi, polisi tidak menemukan identitas korban. Hanya menemukan selembar diary yang ditujukan kepada Tika.Sontak tubuh Tika bergetar. Air matanya mengalir deras lalu tubuhnya limbung dan jatuh pingsan.

\subsection{Tema Percintaan}

Cerpen "Hanya Sesat" mengangkat tema percintaan. Tema ini diawali dengan pertemuan sepasang kekasih masa lalu tanpa disengaja. Peristiwa terjadi di halte, tempat menunggu pemberhentian kendaraan umum pada sore hari menjelang senja di bulan Ramadan. Tokoh utama bernama Tika, sedangkan tokoh protagonis bernama Erward. Tika dan Erward adalah pasangan masa lalu sewaktu keduanya duduk di bangku SMA. Keduanya pernah merajut benih-benih cinta, namun kandas. Erward memutuskan berhenti sekolah dan meninggalkan Tika begitu saja tanpa pesan.

Bising kendaraan dan udara kering di bawah panas terik matahari. Debudebu berterbangan diterpa angin membuat komplit sebagai ujian fisik mental bagi yang melaksanakan puasa ramadan.

Seorang lelaki kurus yang sedari tadi asyik membaca sebuah buku kumal dengan manggut-manggut, sungguh tak menarik. Dengan jeans lusuh serta T-shirt merah kusam plus sikapnya yang acuh sangat memukauku. Disekanya keringat yang ada di tengkuknya...ck...ck... Ya Allah. Diliriknya lagi lelaki itu dan... lelaki itu pun menatapnya... uft! Cepat-cepat dipalingkannya kembali wajahnya memandang lalu-lalang kendaraan (Eko S, 1988:VI).

Dalam kutipan tersebut, pengarang menceritakan suasana Kota Balikpapan yang dipenuhi lalu-lalang pejalan kaki, kendaraan, pedagang asongan serta penjual koran. Waktu yang digambarkan adalah sore hari di bulan ramadan. Selain itu, tepat di pinggir jalan ada sebuah halte, tempat orang-orang duduk menunggu kendaraan umum yang akan mengangkut mereka. Alur yang digunakan adalah alur maju, yakni menceritakan pertemuan Tika dan Edward secara tidak sengaja. Awalnya, Tika tidak mengenali sosok lelaki kurus dengan pakaian kumal yang duduk di bangku sebuah halte. Kemudian, lelaki itu menyapa Tika yang sedari tadi tampak kebingungan mengawasi gerak-geriknya. Tika pun salah tingkah dan memalingkan wajahnya ke arah jalan.

Tika berpikir keras, sepertinya ia pernah mengenalnya, tetapi...di mana! Dengan tetap membaca lelaki itu menegurnya. "Mau ke mana Tika"? Tika kaget setengah mati. Dipandanginya lelaki itu, ia tidak kenal, tetapi ia kok tahu namaku.

Mau ke mana Tika Sari? Lelaki itu mengulangi pertanyaannya, malah menyebut namaku dengan lengkap. Tika masih diam masih mengira-ngira siapa sebenarnya lelaki itu (Eko S, 1988:VI).

Dalam kutipan tersebut, tema yang dimunculkan adalah adegan pertemuan sesaat yang tidak terduga. Kemudian, kedua tokoh dihadapkan pada peristiwa masa lalu. Edward yang lebih dahulu mengingat sosok Tika, berusaha menyapanya dengan ramah. Sementara itu, Tika masih kebingungan dan berusaha mengingat kembali sosok lelaki yang menyapanya. Setelah Edward mengenalkan dirinya pada Tika, seketika itu Tika terperanjak dan merasa tidak percaya kalau lelaki itu adalah Edward, kekasih yang pernah mengisi 
hatinya. Peristiwa selanjutnya mengalir sesuai dengan penggunaan alur campuran, yakni alur maju dan alur mundur (flashback). Munculnyakonflik diawali dengan pertemuan tokoh utama dan tokoh protagonis secara tidak sengaja di sebuah halte sehingga membangkitkan kembali benih-benih cinta keduanya. Pada bagian akhir cerita tokoh utama dihadapkan pada sebuah konflik yang mengejutkan (suspence ending), yakni tokoh utama (Tika) harus rela melepaskan kepergian Edward untuk selamanya, meskipun keduanya belum sempat bertemu.

\subsection{Gejala Sosial Kultural}

Cerpen "Hanya Sesaat" menceritakan kehidupan masyarakat perkotaan yang sibuk dengan aktivitasnya setiap hari. Ada pedagang koran, penjual makanan, pejalan kaki,kendaraan lalu-lalang, dan banyak hal yang menghiasi Kota Balikpapan. Dalam cerpen ini, gejala sosial kultural yang tampak adalah gambaran suasana suci bulan Ramadan. Bulan penuh keberkahan serta menguji kesabaran, keiklasan, dan keimanan sesorang dalam menghadapi hidup setiap hari. Siang menjelang sore, matahari memancarkan sinarnya begitu tajam serta menyengat kulit. Lelah dan haus mengelayut di pikiran orang-orang yang berada di jalanan, termasuk Tika. Sambil mengibaskan sapu tangannya untuk menghindari debu yang beterbangan di udara, Tika terus berjalan menuju sebuah halte yang berada di simpang jalan. Begitu tiba di halte, Tika tersentak kaget melihat sosok lelaki kurus dankumal menegurnya. Tika berusaha mengingat-ingat lelaki muda yang menegurnya itu.

"Aku Edward" kata lelaki itu kalem. Gler! Bagai di sambar petir di siang bolong, Tika mendengar pengakuan Edward. Bagaimana tidak, Edwardlah lelaki pertama yang menempati mahligai nuranainya. Di tatapnya
Edward dalam-dalam, tubuhnya kurus, hitam, tampak dekil bersandal jepit dan seperti tidak ada percaya diri.

“Kau ... Edward..."? Mata Tika berkaca-kaca. Rasanya Tika tidak percaya, sewaktu kelas satu SMA, Edward terkenal konyol dan badung. Namun, nilai rapornya belum ada yang bisa menandingi. Sekarang... sungguh bertolak belakang (Eko S, 1988:VI).

Kutipan tersebut, menunjukkan perubahan status pribadi seseorang yang mengalamikebimbangan serta tidak percaya diri. Hal itu dialami oleh Edward. Tekanan batin yang dialami Edward membuatnya putus asa untuk meneruskan hidup dan masa depannya. Bahkan, janji bertemu dengan Tika terpaksa diingkarinya karena merasa malu dan tidak percaya diri untuk bersama Tika lagi, meskipun Edward masih mencintai Tika. Begitu pula dengan Tika sangat mendambakan Erdward dapat menjalin cinta seperti masa SMA dulu. Namun, semua hanya tinggal angan-angan hampa. Edward memilih menyerah pada takdir dan pergi selamanya meninggalkan Tika. Pertemuan keduanya hanya sesaat dan sangat berarti dalam kenangan Tika.

\section{Cerpen "Antara Yogya-Balikpapan" Karya Irpus (Juni 1988)}

\subsection{Ringkasan Cerita}

Cerpen "Antara Yogya-Balikpapan" mengisahkan percintaan remaja. Andang dan Weny adalah sepasang remaja yang tinggal di Kota Yogyakarta. Keduanya terpisah karena Andang pergi melaksanakan tugas selama lima bulan di Kota Balikpapan. Begitu selesai melaksankan tugas di Kota Balipapan, Andang merasa gembira karena akan pulang ke Yogyakarta bertemu keluarga dan kekasihnya. Sepanjang perjalanan, Andang membayangkan bertemu 
dengan Weny dan berjalan-jalan membeli suvenir kesukaan Weny di Malioboro. Lamunan Andang tiba-tiba pudar karena pesawat yang ditumpanginya segera mendarat di lapangan udara Adi Sucipto. Andang bergegas turun dan berjalan menuju ruang tunggu. Ia berharap akan dijemput oleh Weny. Namun, harapannya itu hanya angan-angan saja. Seorang remaja berusia 15 tahun memanggil namanya lalu menyerahkan sepucuk surat pada Andang. Andang dan anak lelaki itu bergegas menaiki Andong yang sudah menunggunya. Mereka pun berjalan menelusuri jalan-jalan kecil. Sepanjang jalan Andang membuka dan membaca surat dari Weny. Andang terkejut setelah mengetahui isi surat Weny yang menyatakan berpisah dengannya karena Weny beranggapan bahwa Andang tidak setia dan menghianatinya dengan gadis lain selama di Kota Balikpapan. Andang menyuruh Pak kusir memacu kudanya agar segera sampai di rumah Weny. Sesampainya di rumah Weny, Andang meminta Weny menjelaskan sikapnya pada Andang. Setelah Andang dan Weny bertemu dan menceritakan permasalahannya, barulah keduanya sadar bahwa selama ini Baskoro yang ingin menghancurkan hubungan mereka dengan memfitnah Andang telah menikah dengan anak gadis majikannya. Akhirnya, Andang dan Weny kembali merajut cinta kasih dengan kebahagiaan.

\subsection{Tema Percintaan}

Cerpen "Antara Yogya-Balikpapan" mengangkat tema percintaan. Tema ini diawali dengan keretakan dan kesalahpahaman yang dimunculkan oleh orang ketiga. Andang dan Weny adalah sepasang kekasih sejak duduk di bangku sekolah menengah berasal dari Kota Yogyakarta. Keduanya terpisah karena Andang harus melaksanakan tugas di Kota Balikpapan. Pada saat Andang ingin kembali ke Yogyakarta karena selesai menjalankan tugas selama lima bulan, Andang terkejut mendaptkan Weny kekasihnya telah berubah dan menuduhnya telah berkhianat. Andang merasa difitnah oleh Baskoro, orang ketiga dalam hubungan keduanya.
“Sebulan yang lalu Baskoro bercerita bahwa engkau telah menikah dengan gadis anak majikanmu di Balikpapan" ucap Weny dengan marah. "Fitnah"! teriak Andang spontan. "Tega benar Baskoro memfitnah". Kedua mata Ibu Weny bersinar-sinar, "Weny cepat kau minta maaf pada Andang. Engkau telah melakukan kesalahan"! "Maaf- kan saya, mas... saya masih mudah dipengaruhi". Tegas Weny merasa bersalah (Irpus, 1988:V).

Dalam kutipan tersebut, terlihat pengarang menggunakan alur maju. Peristiwa selanjutnya mengalir dengan penggunaan alur campuran, yakni alur maju dan alur mundur (flashback) melalui lamunan tokoh utama terhadap kekasihnya. Munculnya konflik terjadi pada adegan perselisihan antara Andang dan Weny yang diciptakan oleh Baskoro, orang ketika dalam hubungan percintaan mereka. Sebagai lelaki yang bertanggung jawab, Andang berusaha menyadarkan Weny untuk tidak percaya dengan hasutan dan fitnah dari Baskoro, termasuk Ibu Weny juga menyakinkan Weny bahwa Andang pemuda yang baik dan tidak pernah mengkhianati Weny. Baskoro pemuda yang menyukai Weny. Ia berusaha memfitnah Andang agar memisahkan Weny dan Andang. Perbuatan negatif Baskoro akhirnya diketahui oleh Weny. Weny menyadari kesalahannya langsung meminta maaf pada Andang. Keduanya bahagia.

\subsection{Gejala Sosial Kultural \\ Cerpen "Antara Yogya-Balikpapan" menceritakan kehidupan masyarakat}


perkotaan antara dua wilayah, Yogyakarta dan Balikpapan. Tokoh-tokoh tersebut berasal dari Kota Yogyakarta. Kehidupan yang diceritakan di Kota Yogyakarta adalah kesibukan pedagang dan penjalan kaki yang berkeliaran di Malioboro. Sementara itu, kondisi sosial lainnya menceritakan perjalanan hidup tokoh utama (Andang) yang bekerja (magang) selama lima bulan di Kota Balikpapan. Hal ini tergambar dalam lamunan Andang ketika hendak kembali ke Kota Yogyakarta.

“Enam bulan yang silam Andang masih sering menyisiri Malioboro bersama Weny, kekasih tambatan hati. Kini Andang telah melaksanakan kontrak kerja selama lima bulan: Weny tentu bahagia melihat aku pulang..." kata Andang dalam hati diiringi seutas senyum. Keceriaan wajah Weny terlukis indah di matanya" Tiba-tiba Andang tersentak begitu tahu pesawat yang ditumpanginya telah mendarat. Hatinya senang ingin segera bertemu Weny (Irpus, 1988:V).

Kutipan tersebut, menunjukkan adanya gejala sosial kultural yang terjadi dalam pikiran dan lamunan tokoh utama. Hasrat dan harapan Andang ingin segera bertemu kekasih hatinya, Weny tidak dapat dibendungnya lagi. Meskipun pada awalnya, hubungan jarak jauh antara Yogya dan Balikpapan menimbulkan peristiwa yang hampir mengandaskan jalinan cinta Andang dan Weny karena perbuatan Baskoro. Akhirnya, keduanya saling memaafkan. Keduanya hidup berbahagia, saling percaya, dan tidak mudah menerima hasutan yang menghancurkan hubungan cinta mereka.

Keseluruhan tema percintaan yang digambarkan pengarang dalam ketiga cerpen terbitan di surat kabar harian Manuntung periode 1988-1989 memiliki karakteristik yang berbeda dan mengisahkan sepenggal kehidupan tokoh dengan berbagai pertikaian, peristiwa yang mengharukan dan menyenangkan, serta mengandung kesan yang tidak mudah dilupakan oleh tokoh-tokoh dalam ketiga cerpen tersebut sehingga membuat pembaca larut dalam hayalannya.

\section{PENUTUP}

Cerita pendek atau yang disebut cerpen adalah suatu bentuk prosa naratif fiktif. Ada enam unsur intrinsik yang terdapat dalam cerpen, yakni tema, latar, alur, tokoh, perwatakan, dan amanat. Selain Itu, terdapat pula unsur ekstrinsiknya, seperti latar belakang kehidupan pengarang dan situasi sosial kultural ketika cerita itu diciptakan. Tema dalam cerpen menjadi suatu yang dominan keberadaannya, karena tema memiliki peranan yang paling penting dalam membangun sebuah cerita. Oleh karena itu, wajar jika setiap karya sastra yang lahir pasti memiliki tema atau makna yang ingin disampaikan oleh pengarang. Hal tersebut membuat tema sangat penting untuk dikaji karena tema merupakan gagasan utama sebuah cerita.

Kehadiran dan perkembangan cerpen di Kalimantan Timur muncul lebih dahulu dibandingkan dengan puisi. Hal itu juga dipengaruhi oleh peran media massa dalam memasyarakatkan cerpen. Penerbitan cerpen mulai muncul sejak terbitnya harian Manuntung dan media massa lainnya, seperti Meranti, Kaltim Post, Suara Kaltim, Samarinda Post, Membangun Bumi Etam, dan Tribun Kaltim. Pada masa itu, surat kabar harian Manuntung hanya terbit di Kota Balikpapan dan Samarinda (1988 dan 2003). Kemudian, pada tahun 1999 surat kabar Manuntung berubah nama menjadi Kaltim Post. Adapun tema yang diusung dalam cerpen terbitan harian Manuntung sangat bervariasi, di antaranya memuat tema realita 
sosial, polemik keluarga, dan kisah percintaan. Untuk itu, pendeskripsian struktur intrinsik dalam tiga cerpen terbitan di surat kabar harian Manuntung periode 1988-1989 ini lebih difokuskan pada tema percintaan dan gejala sosial kultural.

Cerpen "Kemuning Senja" mengangkat tema percintaan. Kisah percintaanMira dan Swi terjalin selama enam bulan saat mereka sekolah bersama. Mira sangat mengagumi dan membanggakan tokoh Swi, pemuda keturunan Cina yang rendah hati dan berjiwa kesatria tidak membedakan suku, agama, dan golongan. Pengarang menggunakan alur maju yang ditandai dengan munculnya konflik di dalam cerita. Gejala sosial kultural yang tercermin dalam cerpen ini adalah percintaan. Kisah percintaan sepasang remaja yang berbeda suku, golongan, dan keyakinan menjadi warna lokal dalam cerpen ini. Pengarang juga menyelesaikan bagian akhir cerita (resolusi) dengan cara pemecahan masalah sehingga cerita ini berakhir dengan kebahagiaan sepasang kekasih yang berbeda ras dan keyakinan.

Cerpen "Hanya Sesat" mengangkat tema percintaan. Tema ini diawali dengan pertemuan sepasang kekasih masa lalu tanpa disengaja. Tokoh utama bernama Tika, sedangkan tokoh protagonis bernama Erward. Peristiwa dalam cerpen ini mengalir sesuai dengan penggunaan alur campuran, yakni alur maju dan alur mundur (flashback). Munculnyakonflik diawali dengan pertemuan tokoh utama dan tokoh protagonis secara tidak sengaja di sebuah halte sehingga membangkitkan kembali benih-benih cinta keduanya. Namun, pertemuan itu hanya sesaat dan meninggalkan kenangan di hati Tika. Gejala sosial kultural yang tampak adalah gambaran suasana suci bulan Ramadan. Bulan penuh keberkahan serta menguji kesabaran, keiklasan, dan keimanan sesorang dalam menghadapi hidup setiap hari.

Cerpen "Antara Yogya-Balikpapan" mengangkat tema percintaan. Tema ini diawali dengan keretakan dan kesalahpahaman yang dimunculkan oleh orang ketiga. Andang dan Weny adalah sepasang kekasih sejak duduk di bangku sekolah menengah berasal dari Kota Yogyakarta. Keduanya terpisah karena Andang harus melaksanakan tugas di Kota Balikpapan. Dalam cerpen ini pengarang menggunakan alur maju. Selanjutnya,diselingi dengan alur campuran melalui lamunan tokoh utama terhadap kekasihnya. Munculnya konflik terjadi pada adegan perselisihan antara Andang dan Weny yang diciptakan oleh Baskoro, orang ketika dalam hubungan percintaan mereka. Gejala sosial kultural yang muncul dalam cerpen ini adalah hasrat dan harapan yang tidak dapat dibendung lagi oleh tokoh utama agar segera bertemu kekasih hatinya, Weny di Kota Balikpapan.

Analisis tema percintaan dalam ketiga cerita pendek Kalimantan Timur memiliki karakteristik yang berbeda-beda dan menjadi satu kesatuan secara utuh dalam cerita. Karakteristik merupakan ciri-ciri unik dari bentuk fiksi, terutama pada dialog dan perilaku. Oleh karena itu, dapat ditegaskan bahwa dalam kajian fiksi, baik setiap perkataan maupun tindakan bukan hanya menentukan alur saja. Akan tetapi, yang paling utama adalah sebuah manifestasi dari karakter dalam cerita tersebut. Dengan demikian, tema percintaan dalam ketiga cerpen terbitan surat kabar harian Manuntung memiliki kekuatan untuk mendominasi keseluruhan cerita.

\section{DAFTAR PUSTAKA}

Budhilesmana, Bening. Cerpen "Kemuning Senja". Balikpapan: Terbitan Manuntung. (Kamis, 28 April 1988 halaman V). 
Endraswara, Suwardi. 2003. Metodologi Penelitian Sastra Epistemologi, Model, Teori, dan Aplikasi. Yogyakarta: Pustaka Widyatama.

Eko S., Wie, Cerpen "Hanya Sesaat". Balikpapan: Terbitan Manuntung. (Kamis, 5 Mei 1988 halaman VI).

Herawati, Yudianti dkk., 2008. Ikhtisar Sastra Indonesia Kalimantan Timur. Yogyakarta: Tiara Wacana.

Irpus. Cerpen "Antara Yogya-Balikpapan". Balikpapan: Terbitan Manuntung (Kamis, 9 Juni 1988 halaman V).

Nurgiyantoro, Burhan. 2013. Teori Pengkajian Fiksi. Yogyakarta: Gadjah Mada University Press.

Kasnadi dan Sutejo. 2010. Kajian Prosa: Kiat Menyisir Dunia Prosa. Ponorogo: P2MP SPECTRUM.
Sangidu. 2004. Penelitian Sastra: Pendekatam, Teori, Metode, Teknik, dan Kiat. Yogyakarta: Sastra Asia Barat Gajah Mada.

Stanton, Robert. 2012. Teori Fiksi. Yogyakarta: Pustaka Pelajar.

Stanton, Robert. 2012. Teori Fiksi Robert Stanton. Terjemahan Sugihastuti, Rossi Abi Al Irsyad. Yogyakata: Pustaka Pelajar.

Teeuw, A. 2015. Sastra dan Ilmu Satra. Cetakan ke-5. Bandung: PT Dunia Pustaka Jaya.

Wellek, Rene dan Autin Warren. 1990. Teori Kesusastrtaan, terjemahan Melani Budianta. Jakarta: Gramedia. 